\title{
Biogeography
}

\section{A compilation of the birds of La Libertad Region, Peru}

\author{
Una recopilación de las aves de la región de La Libertad, Perú \\ Jano Núñez-Zapata ${ }^{\mathrm{a}, \mathrm{b}, *}$, Luis E. Pollack-Velásquez ${ }^{\mathrm{c}}$, Emiliana Huamán ${ }^{\mathrm{c}}$, \\ Jorge Tiravanti ${ }^{b}$, Edith García ${ }^{b}$ \\ ${ }^{a}$ Departamento de Biología Evolutiva, Facultad de Ciencias, Universidad Nacional Autónoma de México, Apartado postal 70-399, 04510 Ciudad de México, \\ Mexico \\ b Museo de Zoología “Juan Ormea R.”, Universidad Nacional de Trujillo, Jr. San Martín 368, Trujillo, La Libertad, Peru \\ ${ }^{\mathrm{c}}$ Departamento de Biología, Facultad de Ciencias Biológicas, Universidad Nacional de Trujillo, Av. Juan Pablo II s/n, Trujillo, La Libertad, Peru
}

Received 19 May 2015; accepted 7 September 2015

Available online 19 February 2016

\begin{abstract}
We present a list of the species of birds that have been recorded in La Libertad Region, a highly diverse semi-arid region located in northwestern Peru. Records are based on field observations, literature research, and databases of scientific collections. We recorded a total of 484 species in this region. These include 45 endangered species, and 42 species endemic to Peru. This list is intended as a guide for future programs of management and conservation of biodiversity in the region.

All Rights Reserved (C) 2015 Universidad Nacional Autónoma de México, Instituto de Biología. This is an open access item distributed under the Creative Commons CC License BY-NC-ND 4.0.

Keywords: Birds; Checklist; Northwestern Peru; Ecoregions

\section{Resumen}

Presentamos una lista de las especies de aves que han sido documentadas en la región de La Libertad, una región semi-árida muy diversa situada en el noroeste de Perú. Los registros se basan en observaciones de campo, revisión de literatura y bases de datos de colecciones científicas. Se registró un total de 484 especies en esta región. Estos registros incluyen 45 especies amenazadas y 42 endémicas de Perú. Esta lista pretende ser una guía para futuros programas de manejo y conservación de la biodiversidad para la región.

Derechos Reservados @ 2015 Universidad Nacional Autónoma de México, Instituto de Biología. Este es un artículo de acceso abierto distribuido bajo los términos de la Licencia Creative Commons CC BY-NC-ND 4.0.
\end{abstract}

Palabras clave: Avifauna; Listado; Noroeste de Perú; Ecorregiones

\section{Introduction}

Lists of bird species that inhabit a region are fundamental tools for the synthesis of knowledge of biodiversity in a specific geographical area, but also are the basis for further studies in systematics, taxonomy, distribution, evolution, and conservation. Checklists are especially useful in protected areas, and they provide significant information on the distribution and migration

\footnotetext{
* Corresponding author.

E-mail address: janonature@yahoo.com (J. Núñez-Zapata).

Peer Review under the responsibility of Universidad Nacional Autónoma de México.
}

patterns of different species of birds (e.g., Álvarez \& Iannacone, 2008; Núñez-Zapata \& Tiravanti, 2012; Quiñonez \& Tello, 2011; Sullivan et al., 2009; Witt \& Lane, 2009).

Peru holds one of the most diverse bird faunas in the world (Myers, Mittermeier, Mittermeier, da Fonseca, \& Kent, 2000). Its study started early in the ornithological exploration of the Neotropics (Franke, 2007), and has been extensive since the 1960s, increasing the records of birds for different regions (Fjeldså, 1993; Gonzáles \& Málaga, 1997; Graham, Graves, Schulenberg, \& O'Neill, 1980; Hughes, 1970; Parker \& O'Neill, 1985; Parker, 1982; Terborgh, Fitzpatrick, \& Emmons, 1984; Walker, Stotz, Pequeño, \& Fitzpatrick, 2006). Main products of this continuous survey work are general publications and 


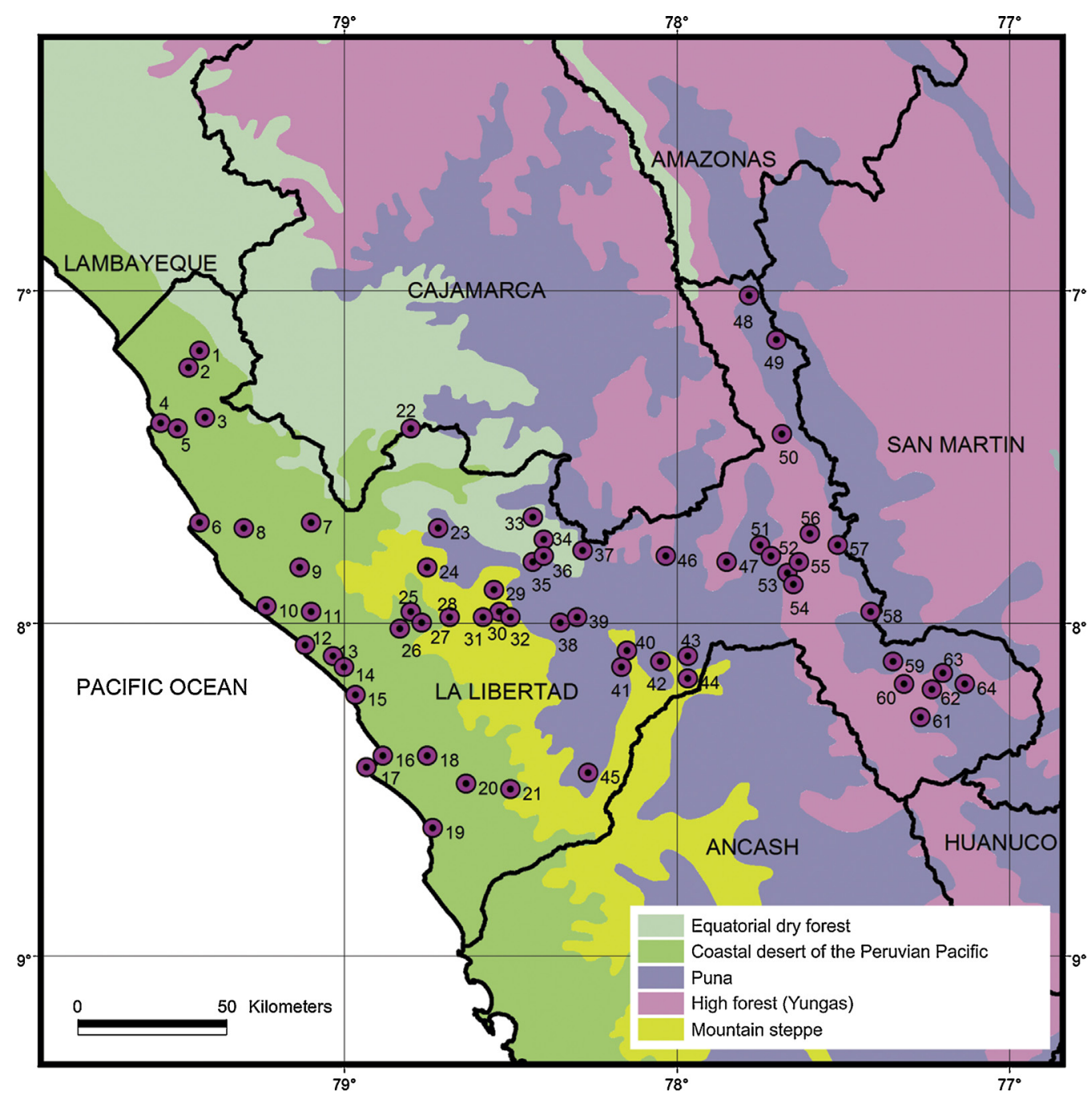

Figure 1. Map of La Libertad Region (Peru) with localities where studies or collections of birds were carried out. 1. Algarrobal El Moro ( $\left.07^{\circ} 11^{\prime} \mathrm{S}, 79^{\circ} 26^{\prime} \mathrm{W}\right), 2$. Guadalupe $\left(07^{\circ} 14^{\prime} \mathrm{S}, 79^{\circ} 28^{\prime} \mathrm{W}\right), 3$. ACPB El Cañoncillo $\left(07^{\circ} 23^{\prime} \mathrm{S}, 79^{\circ} 25^{\prime} \mathrm{W}\right), 4$. Pacasmayo $\left(07^{\circ} 24^{\prime} \mathrm{S}, 7^{\circ} 33^{\prime} \mathrm{W}\right), 5^{\prime}$. San Pedro de Lloc $\left(07^{\circ} 25^{\prime} \mathrm{S}, 79^{\circ} 30^{\prime} \mathrm{W}\right), 6$. Malabrigo-El Tubo $\left(07^{\circ} 42^{\prime} \mathrm{S}, 79^{\circ} 26^{\prime} \mathrm{W}\right), 7$. Ascope $\left(07^{\circ} 42^{\prime} \mathrm{S}, 79^{\circ} 06^{\prime} \mathrm{W}\right), 8$. Paijan $\left(07^{\circ} 43^{\prime} \mathrm{S}, 79^{\circ} 18^{\prime} \mathrm{W}\right)$, 9 . Chicama $\left(07^{\circ} 50^{\prime} \mathrm{S}, 79^{\circ} 08^{\prime} \mathrm{W}\right), 10$. El Brujo $\left(07^{\circ} 57^{\prime}\right.$ S, $\left.79^{\circ} 14^{\prime} \mathrm{W}\right)$, 11. Cerro Campana $\left(07^{\circ} 58^{\prime} \mathrm{S}, 79^{\circ} 06^{\prime} \mathrm{W}\right), 12$. Huanchaco $\left(08^{\circ} 04^{\prime} \mathrm{S}, 79^{\circ} 07^{\prime} \mathrm{W}\right), 13$. Trujillo $\left(08^{\circ} 06^{\prime} \mathrm{S}, 79^{\circ} 02^{\prime} \mathrm{W}\right), 14 . \mathrm{Moche}^{\prime}\left(08^{\circ} 08^{\prime} \mathrm{S}, 79^{\circ} 00^{\prime}\right.$ W), 15. Salaverry $\left(08^{\circ} 13^{\prime} \mathrm{S}, 78^{\circ} 58^{\prime} \mathrm{W}\right), 16$. Puerto Morin $\left(08^{\circ} 24^{\prime} \mathrm{S}, 78^{\circ} 53^{\prime} \mathrm{W}\right), 17$. Cerro Negro $\left(08^{\circ} 26^{\prime} \mathrm{S}, 78^{\circ} 56^{\prime} \mathrm{W}\right), 18$. Viru $\left(08^{\circ} 24^{\prime} \mathrm{S}, 78^{\circ} 45^{\prime} \mathrm{W}\right), 19$. Chao $\left(08^{\circ} 37^{\prime} \mathrm{S}, 78^{\circ} 44^{\prime} \mathrm{W}\right), 20$. Laramie $\left(08^{\circ} 29^{\prime} \mathrm{S}, 78^{\circ} 38^{\prime} \mathrm{W}\right), 21$. Huamanzaña $\left(08^{\circ} 30^{\prime} \mathrm{S}, 78^{\circ} 30^{\prime} \mathrm{W}\right), 22$. Bosque de Cachil $\left(07^{\circ} 25^{\prime} \mathrm{S}, 78^{\circ} 48^{\prime} \mathrm{W}\right), 23$. Llaguen $\left(07^{\circ} 43^{\prime}\right.$ S, $\left.78^{\circ} 43^{\prime} \mathrm{W}\right)$, 24. Sinsicap $\left(07^{\circ} 50^{\prime} \mathrm{S}, 78^{\circ} 45^{\prime} \mathrm{W}\right)$, 25. Simbal $\left(07^{\circ} 58^{\prime} \mathrm{S}, 78^{\circ} 48^{\prime} \mathrm{W}\right)$, 26. Menocucho $\left(08^{\circ} 01^{\prime} \mathrm{S}, 78^{\circ} 50^{\prime} \mathrm{W}\right), 27$. Poroto $\left(08^{\circ} 00^{\prime} \mathrm{S}, 78^{\circ} 46^{\prime} \mathrm{W}\right), 28$. Samne $\left(07^{\circ} 59^{\prime} \mathrm{S}, 78^{\circ} 41^{\prime} \mathrm{W}\right), 29$. Otuzco $\left(07^{\circ} 54^{\prime} \mathrm{S}, 78^{\circ} 33^{\prime} \mathrm{W}\right)$, 30. Agallpampa $\left(07^{\circ} 58^{\prime} \mathrm{S}, 78^{\circ} 32^{\prime} \mathrm{W}\right), 31$. Milluachaqui $\left(07^{\circ} 59^{\prime} \mathrm{S}, 78^{\circ} 35^{\prime} \mathrm{W}\right), 32 . \mathrm{Motil}^{\prime}\left(07^{\circ} 59^{\prime}\right.$ S, $\left.78^{\circ} 30^{\prime} \mathrm{W}\right), 33$. Huaranchal $\left(07^{\circ} 41^{\prime} \mathrm{S}, 78^{\circ} 26^{\prime} \mathrm{W}\right), 34$. Chuquizonco $\left(07^{\circ} 45^{\prime} \mathrm{S}, 78^{\circ} 24^{\prime} \mathrm{W}\right)$, 35. Charat $\left(07^{\circ} 49^{\prime} \mathrm{S}, 78^{\circ} 26^{\prime} \mathrm{W}\right), 36$. Usquil $\left(07^{\circ} 48^{\prime} \mathrm{S}, 78^{\circ} 24^{\prime} \mathrm{W}\right)$, 37. Shitauar $\left(07^{\circ} 47^{\prime} \mathrm{S}, 78^{\circ} 17^{\prime} \mathrm{W}\right)$, 38. Shorey $\left(08^{\circ} 00^{\prime} \mathrm{S}, 78^{\circ} 21^{\prime} \mathrm{W}\right)$, 39. Quiruvilca $\left(07^{\circ} 59^{\prime} \mathrm{S}, 78^{\circ} 18^{\prime} \mathrm{W}\right)$, 40. Cachicadan $\left(08^{\circ} 05^{\prime} \mathrm{S}, 78^{\circ} 09^{\prime} \mathrm{W}\right), 41 . \mathrm{S}^{\circ}$ Santiago de Chuco $\left(08^{\circ} 08^{\prime} \mathrm{S}, 78^{\circ} 10^{\prime} \mathrm{W}\right), 42$. Angasmarca $\left(08^{\circ} 07^{\prime} \mathrm{S}, 78^{\circ} 03^{\prime} \mathrm{W}\right), 43$. Tulpo $\left(08^{\circ} 06^{\prime} \mathrm{S}, 77^{\circ} 58^{\prime} \mathrm{W}\right), 44$. Mollebamba $\left(08^{\circ} 10^{\prime} \mathrm{S}, 77^{\circ} 58^{\prime} \mathrm{W}\right), 45 . \mathrm{Calipuy}^{\circ}\left(08^{\circ} 27^{\prime} \mathrm{S}\right.$, $\left.78^{\circ} 16^{\prime} \mathrm{W}\right), 46$. Huamachuco $\left(07^{\circ} 48^{\prime} \mathrm{S}, 78^{\circ} 02^{\prime} \mathrm{W}\right)$, 47. Cochabamba ( $\left.07^{\circ} 49^{\prime} \mathrm{S}, 77^{\circ} 51^{\prime} \mathrm{W}\right)$, 48. Las Quinuas $\left(07^{\circ} 01^{\prime} \mathrm{S}, 7^{\circ} 47^{\prime} \mathrm{W}\right), 4^{4}$. Bolívar $\left(07^{\circ} 09^{\prime} \mathrm{S}, 77^{\circ} 42^{\prime} \mathrm{W}\right)$, 50. Bambamarca $\left(07^{\circ} 26^{\prime} \mathrm{S}, 77^{\circ} 41^{\prime} \mathrm{W}\right)$, 51. El Molino $\left(07^{\circ} 46^{\prime} \mathrm{S}, 77^{\circ} 45^{\prime} \mathrm{W}\right)$, 52. Aricapampa $\left(07^{\circ} 48^{\prime} \mathrm{S}, 77^{\circ} 43^{\prime} \mathrm{W}\right)$, 53 . Soquian $\left(07^{\circ} 51^{\prime} \mathrm{S}, 77^{\circ} 40^{\prime} \mathrm{W}\right), 54$. Succha $\left(07^{\circ} 53^{\prime} \mathrm{S}, 77^{\circ} 39^{\prime} \mathrm{W}\right), 55$. Chagual $\left(07^{\circ} 49^{\prime} \mathrm{S}, 77^{\circ} 38^{\prime} \mathrm{W}\right)$, 56. Pataz $\left(07^{\circ} 44^{\prime} \mathrm{S}, 77^{\circ} 36^{\prime} \mathrm{W}\right)$, 57. Chigualen $\left(07^{\circ} 46^{\prime} \mathrm{S}, 77^{\circ} 31^{\prime} \mathrm{W}\right), 58$. Parcoy $\left(07^{\circ} 58^{\prime} \mathrm{S}, 77^{\circ} 25^{\prime} \mathrm{W}\right)$, 59. Buldibuyo $\left(08^{\circ} 07^{\prime} \mathrm{S}, 77^{\circ} 21^{\prime} \mathrm{W}\right)$, 60. Huaylillas $\left(08^{\circ} 11^{\prime} \mathrm{S}, 77^{\circ} 19^{\prime} \mathrm{W}\right)$, 61. Tayabamba $\left(08^{\circ} 17^{\prime} \mathrm{S}, 77^{\circ} 16^{\prime} \mathrm{W}\right), 62$. Mashua $\left(08^{\circ} 12^{\prime} \mathrm{S}, 77^{\circ} 14^{\prime} \mathrm{W}\right), 63$. Cumpang $\left(08^{\circ} 09^{\prime} \mathrm{S}, 77^{\circ} 12^{\prime} \mathrm{W}\right), 64$. Utcubamba $\left(08^{\circ} 11^{\prime} \mathrm{S}, 77^{\circ} 08^{\prime} \mathrm{W}\right)$. Ecoregions follow official names provided by MINAM and described in Material and methods section.

annotated field-guides of birds of the whole country (Clements \& Shany, 2001; Schulenberg, Stotz, Lane, O’Neill, \& Parker III, 2007), which include distributional information about species and notes on their ecology, behavior, and taxonomy. However, biological surveys have been geographically uneven, being more frequent in the Andes and the Amazonian regions, while other areas remain little or unexplored (Mark, Augustine, Barrio, Flanagan, \& Vellinga, 2008).
La Libertad is a region of the northwestern section of the country (Fig. 1) where few studies of birds have been performed; most of those have concentrated on the coast (Becerra, 1981; Meléndez, 1976; Pollack-Velásquez et al., 2003; VallejosVardales, Saldaña-Ugaz, Pollack-Velásquez, \& Tiravanti, 2013), therefore there is only limited information about birds of the other ecosystems in the area. This broad area is the southern limit for many bird species characteristic of the Tumbesian region, 
while on its eastern side occur taxa restricted to the Marañón basin and the central Andes (Flanagan, Franke, \& Salinas, 2005; Valqui, 2004), conferring this region a special biological significance.

In this contribution we report the first compilation of birds present in La Libertad. The list is based on several sources of information (scientific literature, museum collections, and extensive field work by the authors); we also highlight some aspects on the general distribution of species, endemism, and the species facing threats.

\section{Material and methods}

La Libertad Region (Fig. 1) is located in northwestern Peru, between $6^{\circ} 56^{\prime} 38^{\prime \prime}$ and $8^{\circ} 58^{\prime} 40^{\prime \prime} \mathrm{S}, 79^{\circ} 27^{\prime} 9^{\prime \prime}$ and $79^{\circ} 41^{\prime} 18^{\prime \prime} \mathrm{W}$, with a total area of $25,569 \mathrm{~km}^{2}$ and elevations ranging from sea level to 4,730 m (Banco Central de Reserva del Perú, 2004; Gastelo, Alva, del Busto, Kauffmann, \& Vásquez, 2004). For better observation of the data in a biogeographic context, the region was subdivided following the last update of the "Ecoregions of Peru" provided by the Ministerio de Ambiente (2011). This subdivision is based on Brack (1986), who considered a total of 11 ecoregions in Peru based on bioclimates, soil, vegetation, and chorology of important species of flora and fauna data. According to MINAM, 5 of these ecoregions converge in La Libertad: (1) Bosque Seco Ecuatorial (Equatorial Dry Forest - EDF), which includes mangrove forest; (2) Desierto del Pacífico (Pacific Desert - PD), with desert vegetation in coastal hills and riparian formations; (3) Serranía Esteparia (Andean steppe - AS) which includes seasonally dry tropical forest, sub-xerophytic relict forests, and montane cloud forests in western Andes, and (4) Puna (Puna - P), which occurs above $3,800 \mathrm{~m}$ and is mostly covered by grasses and some patches of quinual trees (Polylepis spp.); and (5) Selva Alta or Yungas (Yungas - Y), a sub-humid rainforests, observable throughout most of the premountain-mountain stratum in the Andean Amazon, and includes mountain rainforest and premountain humid forest in the eastern Andes. Detailed descriptions of the ecoregions' attributes are available in Reynel, Pennington, and Särkinen (2013).

Field trips and observational surveys in different localities, mainly on the coast and the western slope of Andes, were carried out from January 1998 to December 2012 (Fig. 1); species records are supported by observations, sound recordings, specimens, and/or photographs. The information was supplemented with records from the scientific literature (e.g., Mark et al., 2008; Pollack-Velásquez, Zelada, Medina, \& Tiravanti, 2009; Salvin, 1895) and records obtained from natural history museums databases: Louisiana Museum of Natural History (LSUMZ); Museum of Vertebrate Zoology, University of California, Berkeley (MVZ); Field Museum of Natural History (FMNH); Muséum National d'Histoire Naturelle (MNHN); Academy of Natural Sciences (ANSP); and Centro de Ornitología y Biodiversidad (CORBIDI) in Lima. Additional information was obtained from revision of theses, congress proceedings, and technical reports (see Appendix), which were carefully analyzed to avoid including dubious uncertain data.

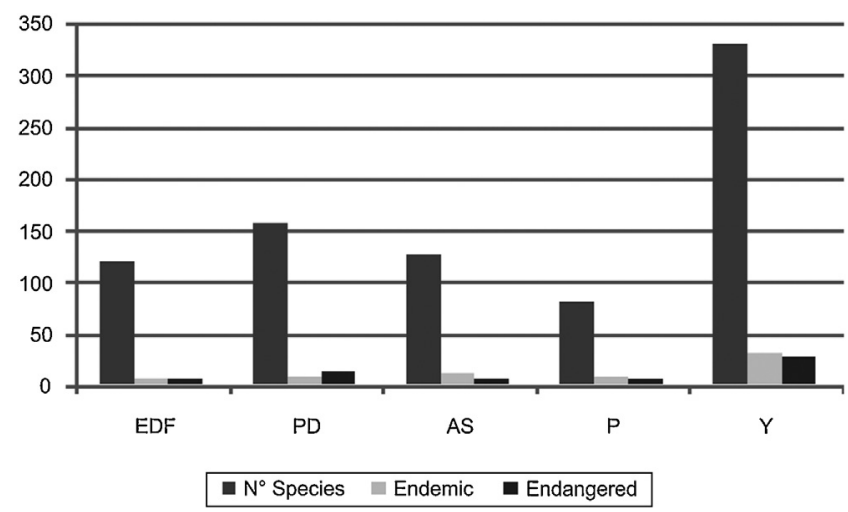

Figure 2. Number of species from La Libertad by ecoregion.

Scientific names and taxonomic order follow the current version of the South American Classification Committee (SACC; Remsen et al., 2015), with exceptions in some species of doubtful taxonomic status. The conservation status of the species follows BirdLife International (2015a), and the current Peruvian legislation (Ministerio de Agricultura, 2014). The general distribution of species was compared with the maps by Ridgely and Tudor (1994), Schulenberg et al. (2007), and BirdLife International (2015a).

\section{Results}

A total of 484 species belonging to 63 families (Appendix) was recorded for La Libertad. Greater than $85 \%$ of the species records are supported by a voucher specimen, $37 \%$ of species were observed in field, and fewer than $4 \%$ of the records were solely documented in unpublished theses or technical reports. The vast majority of species have resident populations ( $>90 \%)$, but we also recorded species that are austral or boreal migrants $(\sim 8 \%)$.

Species richness is uneven between ecoregions; the Peruvian Yungas host the highest number of species $(\approx 70 \%)$ whereas the other ecoregions host between $14 \%$ and $34 \%$ of species (Fig. 2). At the same time, important numbers of endemic and endangered species have been documented. A total of 42 Peruvian endemic species ( $8.7 \%$ of the total) have been reported in the region, with a large majority (30) recorded on the Peruvian Yungas. Further, 45 species (9.3\% of the total) are considered in different categories of risk according to either BirdLife International (2015a), or Peruvian legislation (Ministerio de Agricultura, 2014).

\section{Discussion}

La Libertad represents $2 \%$ of the total area of the country, but hosts approximately $40 \%$ of the birds that have been recorded in Peru. Although this number is not comparable with Amazonian biodiversity (Patterson, Stotz, Solari, Fitzpatrick, \& Pachecho, 1998; Terborgh et al., 1984), the extension of the territory and the different ecosystems that it holds play an important role in conservation and sustainability of avian populations. In this study we did not include sea birds because of the lack of precise documentation of records, but distributional maps in Schulenberg 
et al. (2007) document several species $(\sim 30)$ that are potentially present along the coastline of the region.

\section{Extension of distributional ranges}

The known distribution range was increased significantly for populations of some species detected in La Libertad. Cactus Canastero (Pseudasthenes cactorum) and Great Inca-finch (Incaspiza pulchra) are two clear examples of northward range extensions (Núñez-Zapata \& Tiravanti, 2012). A main factor explaining our ignorance on the distribution of species is the lack of studies in similar areas. As another example, LoPresti and Angulo-Pratolongo (2014) recently reported new coastal localities for the Great Inca-finch and the Masked Duck (Nomonyx dominicus). For other species that we report herein (e.g., Forpus xanthopterygius, Glaucidium brasilianum, Tangara chilensis, Tangara schrankii, Dacnis cayana, Thraupis palmarum, Dixiphia pipra, and Cardellina canadensis), published distribution maps (Schulenberg et al., 2007) exclude La Libertad, but our data confirm that these species are present in the region, occupying a thin strip along the eastern boundary of the region (e.g., Tayabamba, Mashua, Cumpang, and Utcubamba).

\section{Endangered species and endemism}

Although La Libertad hosts fewer than $3 \%$ of the endangered bird species listed for Peru, it includes 45 species of national and worldwide conservation concern. There are incompatibilities between threatened status of species (Appendix); BirdLife International (2015a) consider 43 threatened species, whereas the Ministerio de Agricultura (2014) consider only 33. Following BirdLife International (2015a), which takes into account the global population distribution, no species is considered critically endangered, but 9 species are "endangered", 12 are "vulnerable", and 22 are "near threatened" (Appendix); the other 2 species (Sula variegata and Falco peregrinus), considered as "least concern", are listed (as endangered and near threatened, respectively) by the Ministerio de Agricultura (2014). Moreover, some of these taxa are also endemic to Peru (e.g., Aglaeactis aliciae, Aulacorhynchus huallagae, Synallaxis zimmeri, Thripophaga berlepschi, Myiarchus semirufus, Phytotoma raimondii, Cnemathraupis aureodorsalis, Poospiza alticola, and Poospiza rubecula). In the last 10 years, the number of threatened species of birds inhabiting La Libertad have increased; comparisons of Peruvian legislation for two periods (Ministerio de Agricultura, 2004, 2014) added six more species (indicated in Appendix with $\ddagger$ ); however, few of these decisions are based on scientific studies due to the lack of detailed biological information for most of the species listed.

Although Peruvian endemic species represent a small percentage of the regional list, fewer than $3 \%$ of total Peruvian birds, they account for close to $45 \%$ of the total endemic Peruvian avifauna (Angulo-Pratolongo, 2009). However, four of these species have a higher degree of importance because their populations are almost exclusively restricted to La Libertad (Schulenberg et al., 2007): Yellow-faced Parrotlet (Forpus xanthops), Purple-backed Sunbeam (A. aliciae), Great Spinetail
(Synallaxis hypochondriaca), and Unicolored Tapaculo (Scytalopus unicolor). The remaining endemic species (e.g., $P$. raimondii, Incaspiza personata, and S. zimmeri) are shared with nearby regions (e.g., Ancash, Lambayeque, Cajamarca, and Lima); however, it is still necessary to perform ecological studies to determine the population sizes and health of these remarkable taxa in the region.

Our list also includes some species that could be considered as vagrants or accidentals to the region. This is the case of the Masked Duck (Nomonyx dominicus) and the White Ibis (Eudocimus albus), which were only observed occasionally by our team during field trips. Populations of these species commonly occupy other Peruvian ecosystems such as mangroves or Amazonian lowland forest (Clements \& Shany, 2001; Schulenberg et al., 2007). Although the records included only a single individual per species, future records of other similar species or a greater number of individuals could indicate substantial changes in the distributional ecology of these species.

\section{Taxonomic considerations}

Conservation biology is linked inextricably with systematic biology. A correct taxonomic identification of birds is a vital step toward investigating further aspects of the biology of these organisms (Cotterill, 1995). During the revision of this manuscript we found some incompatibilities between current SACC (Remsen et al., 2015) names, BirdLife International (2015a) proposal for the nomenclature of endangered taxa, and the other sources of information. Moreover, use of molecular data in recent taxonomic studies involving birds of Peru (e.g., Bonaccorso, Guayasamin, Peterson, \& Navarro-Sigüienza, 2011; Derryberry et al., 2010) is modifying the current systematics, and therefore the species delimitation and formal names of birds. As a result, the number of species found in La Libertad may vary due to species splits. For example, some taxa present in the region; may be added, such as the toucanets Aulacorhynchus atrogularis and Aulacorhynchus cyanolaemus, now considered as different species level taxa from Aulacorhynchus prasinus (Bonaccorso et al., 2011; del Hoyo \& Collar, 2014; Puebla-Olivares et al., 2008). Similarly, the Blue-cowled barbet (Eubucco steerii) is considered as a different taxon from the Versicolored barbet (Eubucco versicolor; BirdLife International, 2015b) based on the discrete variation of color patterns (del Hoyo \& Collar, 2014). Other names of birds present at La Libertad only have to be updated and replaced, such as Psittacara wagleri by Psittacara frontalis, or Pionus tumultuosus by Pionus seniloides; in both cases BirdLife International (2015a) suggested the latter names based on their distribution, although SACC considers both cases as the same species, or concludes that additional studies are needed (Remsen et al., 2015).

\section{Biogeography}

For a better interpretation of birds in a biogeographical context, we used ecoregions, which are defined as relatively large units of land containing a distinct assemblage of natural communities and species that share similar environmental conditions 
and interact ecologically for long-term persistence (Morrone \& Escalante, 2012; Olson et al., 2001). Several systems of classification have been proposed for ecoregions of Peru (see Reynel et al., 2013); however, one of the most used is the proposal of Brack (1986) due to its clear representation of the biomes in the country, the use of bioclimatic and corologic data as criteria, and a continuous updating; furthermore, this map is suggested as the main consensus classification of ecoregions in Peru (Ministerio de Ambiente, 2011). Other similar maps, which were partially congruent with our designation, were not used given that they did not consider appropriate local information (Terrestrial Ecoregions of the World; Olson et al., 2001), or include ecoregions with controversial status (e.g., paramos, Reynel et al., 2013; Zamora, 1996).

Yungas is the ecoregion of most special interest for birds in $\mathrm{La}$ Libertad, considering the number of species ( $\sim 70 \%$ of the total) and endemic taxa ( 31 species, most of them in the cloud forests) recorded (Fig. 2). This ecoregion includes the Marañón Valley, which is considered one of the most important biogeographic boundaries in the Andes due to its environmental complexity, and because it harbors a very unique biodiversity for several taxa (Angulo-Pratolongo, Palomino, Arnal, Aucca, \& Uchofen, 2008; Koch, 2014; Särkinen et al., 2011; Venegas, Townsend, Koch, \& Böhme, 2008). The Marañón Valley, considered also as a different ecoregion by other authors (Olson et al., 2001; Reynel et al., 2013), apparently limits the distribution of several species of birds (e.g., F. xanthops and S. hypochondriaca) from the north-central Andes, and creates an important area of endemism (Barrio, 2007; Mark et al., 2008; Valqui, 2004). The Yungas ecoregion also includes cloud forests to the southeast, the area with the highest species richness in La Libertad. In this ecosystem, birds of the highlands (e.g., Notoprocta curvirostris, and Vanellus resplendens) coexist with species typical of the temperate forests of the west-central Andes (e.g., Coeligena violifer, Margarornis squamiger, and Pipreola intermedia), surely due to the presence of patches of high Andean humid temperate forests located below the Puna ecoregion (Barrio, 2007; Mark et al., 2008).

The other ecoregions host lower species richness ( $~ 80-160)$, and few endemic species (5-12). However, they are not equivalent to one another because they harbor species that are adapted to specific habitats. We found that approximately $60 \%$ (considering only endemic species) are present in more than one ecoregion. We emphasize records in the Equatorial Dry Forest ecoregion, where 19 native species of the Tumbesian region (Forpus coelestis, Nyctidromus anthonyi, Myrmia micrura, P. raimondii, Tumbezia salvini, Ochthoeca piurae, Myiodynastes bairdii, M. semirufus, Thamnophilus bernardi, Geositta peruviana, Synallaxis stictothorax, Cantorchilus superciliaris, Basileuterus trifasciatus, Icterus graceannae, Sicalis taczanowskii, Piezorhina cinerea, Sporophila simplex, and Atlapetes seebohmi) were recorded. The EDF is part of the larger Tumbesian region that extends from western Ecuador to northwestern Peru, an area that is considered a biological hotspot for hosting a significant number of endemic (PeruvianEcuadorian) bird species (Flanagan et al., 2005; Myers et al., 2000; Stattersfield, Crosby, Long, \& Wege, 1998). Despite its small area in La Libertad (Fig. 1), a total of 120 species of birds were recorded in this ecoregion.

The different species richness in each ecoregion reflects a complex biogeographic history for birds of La Libertad. Current phylogeographic studies attributed this diversity and endemism to the dynamic history of orogeny and climatological shifts since the mid-Neogene in the Andes (Rull, 2011). However, other events (e.g., migrations, colonizations, and fragmentation of habitat) can influence the distribution of species, or populations, in the region.

\section{Conservation}

Ecosystems in La Libertad, and therefore the inhabiting bird populations, face a wide range of threats. During our explorations, we witnessed deforestation for firewood extraction and wood, which represent the main problems in the Equatorial Dry Forest and Yungas ecoregions. These modifications are reducing the available habitat of endemic species of the tumbesian region (e.g., P. raimondii, Pollack-Velásquez et al., 2009; Ochthoeca piurae, Tumbezia salvini, Flanagan et al., 2005). Mining and the expansion of agricultural limits are the main threats in the Puna and Yungas ecoregions, which could lead to a drastic decline in bird populations, especially those that are threatened (e.g., A. aliciae, Lambert \& Angulo-Pratolongo, 2007; F. xanthops, BirdLife International, 2015a). Other threats are the presence of livestock overgrazing and illegal hunting (including trafficking some species as pets). The current situation results in highly fragmented landscapes (Flanagan et al., 2005; Franke, 1994; Rodríguez \& Mora, 1994), with an uncertain future for bird populations. Five protected areas exist in La Libertad (Ministerio de Ambiente, 2015), two located in the Pacific Desert (El Cañoncillo and Puquio Santa Rosa), two in the PunaAndes steppe (Sanctuary and Reserve of Calipuy), and one in the Equatorial Dry Forest (Sunchubamba Hunting Reserve); but, there are no protected areas in Yungas region, where our study reports the greatest avifaunal diversity. As an alternative, four Important Birds Areas (IBAS: Llaguén, El Molino, Abiseo River-Tayabamba, and Chao-Corcovado-Santa-Ferrol Islands) were suggested by Angulo-Pratolongo (2009), a conservation program aimed at generated a prioritization scheme for preserving birds and their habits. However, no government actions have been implemented yet to promote this program and transform prioritized areas into "real" protected areas. According to our results, a monitoring program within IBAS, as well as in different localities along the Marañón Valley and eastern slope of the Andes (e.g., Utcubamba, Ongón) would help to assess the status of bird populations, and probably the designation of new protected areas, which are much needed in $\mathrm{La}$ Libertad.

\section{Acknowledgments}

To Van Remsen and Steve Cardiff for providing information from LSU databases, Todd Mark for providing information from ANSP, MNHN and AMNH databases; Manuel Plenge for providing information from MVZ and FMNH databases; 
Thomas Valqui for providing database of CORBIDI and for their contributions to this work, and to Ministerio de Ambiente (Peru) for providing maps and geographic data of Peruvian ecoregions. Also, to Adolfo Navarro and Luis A. Sánchez
(MZFC - UNAM) for comments on different versions of this paper. This study was supported by CORBIDI, the Biological Sciences Faculty of National University of Trujillo, and a posdoctoral fellowship of DGAPA-UNAM to J.N.-Z.

Appendix. List of birds of La Libertad Region (Peru). Classification follows SACC (Remsen et al., 2015). Evidence (EVD): (o) observations in the field, and (s) specimens in scientific collections. Support source (SS): 1. LSUMZ, 2. MVZ, 3. FMNH, 4. MNHN, 5. ANSP, 6. CORBIDI, 7. Abanto and Carcelen (2005), 8. Álvarez (2001), 9. Ávalos (1997), 10. Barrio (2007), 11. Becerra (1981), 12. de la Cruz (1996), 13. Franke (1994), 14. Guarniz (1997), 15. Herrera (1980), 16. Senner and Angulo-Pratolongo (2014), 17. Plascencia (2001), 18. Salvin (1895), 19. Valqui (2004), 20. Martin-Alva, Florián Medina, and Díaz Pillasca (2013), 21. Schmitt et al. (2013). Conservation status (CS): EN - endangered, VU - vulnerable, NT near threatened, LC - least concern, e - endemic; boldCS follows Ministerio de Agricultura (2014).

\begin{tabular}{|c|c|c|c|}
\hline Taxon & EVD & SS & $\mathrm{CS}$ \\
\hline \multicolumn{4}{|l|}{ Tinamidae } \\
\hline Crypturellus obsoletus & s & 1 & \\
\hline Nothoprocta ornata & & 15 & \\
\hline Nothoprocta pentlandii & $0, \mathrm{~s}$ & $3,4,6,15,19,21$ & \\
\hline Nothoprocta curvirostris & $\mathrm{s}$ & $5,6,19$ & \\
\hline \multicolumn{4}{|l|}{ Anatidae } \\
\hline Lophonetta specularioides & s & 5 & \\
\hline Anas flavirostris & & 10 & \\
\hline Anas bahamensis & o & & \\
\hline Anas cyanoptera & $0, \mathrm{~s}$ & $4,7,11$ & \\
\hline Nomonyx dominicus & $\mathrm{o}, \mathrm{p}$ & & \\
\hline Oxyura jamaicensis & $\mathrm{o}, \mathrm{s}$ & 1 & \\
\hline \multicolumn{4}{|l|}{ Cracidae } \\
\hline Chamaepetes goudotti & $\mathrm{s}$ & 5 & \\
\hline Penelope montagnii & $\mathrm{s}$ & 1,4 & \\
\hline \multicolumn{4}{|l|}{ Odontophoridae } \\
\hline Odontophorus speciosus & s & 1 & NT, LC \\
\hline \multicolumn{4}{|l|}{ Podicipedidae } \\
\hline Rollandia rolland & o & 14 & \\
\hline Podilymbus podiceps & & 7 & \\
\hline \multicolumn{4}{|l|}{ Pelecanidae } \\
\hline Pelecanus thagus & o & 8,14 & NT, EN \\
\hline \multicolumn{4}{|l|}{ Sulidae } \\
\hline Sula nebouxii & o & 8 & \\
\hline Sula variegata & o & 8,14 & LC, EN \\
\hline \multicolumn{4}{|l|}{ Phalacrocoracidae } \\
\hline Phalacrocorax brasilianus & o & 8 & \\
\hline Phalacrocorax bougainvillii & & 8,14 & NT, NT \\
\hline \multicolumn{4}{|l|}{ Ardeidae } \\
\hline Nycticorax nycticorax & o & 7,8 & \\
\hline Butorides striata & o & $7,11,17,18$ & \\
\hline Bubulcus ibis & o & $7,9,12,20$ & \\
\hline Ardea cocoi & o & & \\
\hline Ardea alba & o & $7,8,11,14$ & \\
\hline Egretta tricolor & o & 14 & \\
\hline Egretta thula & o & $7,8,11,14$ & \\
\hline Egretta caerulea & o & $7,8,15,14$ & \\
\hline \multicolumn{4}{|l|}{ Threskiornithidae } \\
\hline Eudocimus albus & o & & \\
\hline Plegadis ridgwayi & o & & \\
\hline \multicolumn{4}{|l|}{ Cathartidae } \\
\hline Cathartes aura & o & $7,8,11,15,21$ & \\
\hline Coragyps atratus & o & $7,9,11,12,15,17,20$ & \\
\hline Vultur gryphus & o & 15 & NT, EN \\
\hline
\end{tabular}


Appendix (Continued)

\begin{tabular}{|c|c|c|c|}
\hline Taxon & EVD & SS & $\mathrm{CS}$ \\
\hline $\begin{array}{l}\text { Phoenicopteridae } \\
\text { Phoenicopterus chilensis }\end{array}$ & o & & NT, NT \\
\hline $\begin{array}{l}\text { Pandionidae } \\
\text { Pandion haliaetus }\end{array}$ & o & 7 & \\
\hline $\begin{array}{l}\text { Accipitridae } \\
\text { Circus cinereus } \\
\text { Accipiter striatus } \\
\text { Geranoaetus melanoleucus } \\
\text { Geranoaetus polyosoma } \\
\text { Buteo platypterus } \\
\text { Rupornis magnirostris } \\
\text { Parabuteo unicinctus } \\
\text { Parabuteo leucorrhous }\end{array}$ & $\begin{array}{l}\mathrm{o}, \mathrm{s} \\
\mathrm{o}, \mathrm{s} \\
\mathrm{o}, \mathrm{s} \\
\mathrm{o} \\
\mathrm{o}\end{array}$ & $\begin{array}{l}4 \\
1,21 \\
2,5,21 \\
7,21 \\
21 \\
21 \\
21\end{array}$ & \\
\hline $\begin{array}{l}\text { Rallidae } \\
\text { Pardirallus sanguinolentus } \\
\text { Gallinula galeata } \\
\text { Porphyrio martinicus } \\
\text { Fulica ardesiaca }\end{array}$ & $\begin{array}{l}\mathrm{o}, \mathrm{s} \\
\mathrm{o} \\
\mathrm{o} \\
\mathrm{o}\end{array}$ & $\begin{array}{l}4,7,11,17,18 \\
7,8,11,14,17 \\
11\end{array}$ & \\
\hline $\begin{array}{l}\text { Charadriidae } \\
\text { Vanellus resplendens } \\
\text { Pluvialis squatarola } \\
\text { Pluvialis dominica } \\
\text { Charadrius semipalmatus } \\
\text { Charadrius vociferus } \\
\text { Charadrius nivosus } \\
\text { Charadrius collaris } \\
\text { Charadrius wilsonia }\end{array}$ & $\begin{array}{l}\mathrm{o} \\
\mathrm{o}\end{array}$ & $\begin{array}{l}4,10,15 \\
5,14,16 \\
16 \\
7,8,14,16 \\
7,8,14,16 \\
8,16 \\
16 \\
16\end{array}$ & NT, LC \\
\hline $\begin{array}{l}\text { Haematopodidae } \\
\text { Haematopus palliatus }\end{array}$ & o & 16 & \\
\hline $\begin{array}{l}\text { Recurvirostridae } \\
\text { Himantopus mexicanus }\end{array}$ & o & $8,14,16$ & \\
\hline $\begin{array}{l}\text { Burhinidae } \\
\text { Burhinus superciliaris }\end{array}$ & o & 7 & \\
\hline $\begin{array}{l}\text { Scolopacidae } \\
\text { Gallinago paraguaiae } \\
\text { Limnodromus griseus } \\
\text { Numenius phaeopus } \\
\text { Actitis macularius } \\
\text { Tringa melanoleuca } \\
\text { Tringa flavipes } \\
\text { Tringa semipalmata } \\
\text { Tringa incana } \\
\text { Arenaria interpres }\end{array}$ & $\begin{array}{l}\mathrm{s} \\
\mathrm{o} \\
\mathrm{o} \\
\mathrm{o}, \mathrm{s} \\
\mathrm{o} \\
\mathrm{o}\end{array}$ & $\begin{array}{l}1,2,5 \\
16 \\
8,14,16 \\
5,16 \\
16 \\
8,16 \\
16 \\
16 \\
8,16\end{array}$ & \\
\hline $\begin{array}{l}\text { Calidris alba } \\
\text { Calidris pusilla }\end{array}$ & $\begin{array}{l}\mathrm{o}, \mathrm{s} \\
\mathrm{o}\end{array}$ & $\begin{array}{l}5,8,16 \\
14,16\end{array}$ & NT, LC \\
\hline Calidris mauri & $\mathrm{o}$ & 16 & \\
\hline $\begin{array}{l}\text { Calidris minutilla } \\
\text { Calidris bairdii }\end{array}$ & $\begin{array}{l}\mathrm{s} \\
\mathrm{s}\end{array}$ & $\begin{array}{l}3,16 \\
2,16\end{array}$ & \\
\hline $\begin{array}{l}\text { Calidris himantopus } \\
\text { Calidris canutus } \\
\text { Calidris melanotos }\end{array}$ & o & $\begin{array}{l}16 \\
16\end{array}$ & \\
\hline $\begin{array}{l}\text { Phalaropus tricolor } \\
\text { Phalaropus lobatus } \\
\text { Limosa haemastica } \\
\text { Limosa fedoa }\end{array}$ & $\begin{array}{l}\mathrm{o} \\
\mathrm{s}\end{array}$ & $\begin{array}{l}5,8 \\
16 \\
16\end{array}$ & \\
\hline $\begin{array}{l}\text { Thinocoridae } \\
\text { Thinocorus orbignyianus }\end{array}$ & s & $2,4,5$ & \\
\hline
\end{tabular}


Appendix (Continued)

\begin{tabular}{|c|c|c|c|}
\hline Taxon & EVD & SS & $\mathrm{CS}$ \\
\hline \multicolumn{4}{|l|}{ Laridae } \\
\hline Larus belcheri & o & 8 & \\
\hline Larus dominicanus & & 8,14 & \\
\hline Leucophaeus modestus & o & 14 & \\
\hline Leucophaeus atricilla & & $8,14,17$ & \\
\hline Leucophaeus pipixcan & o & 14 & \\
\hline Thalasseus sandvicensis & o & & \\
\hline \multicolumn{4}{|l|}{ Rynchopidae } \\
\hline Rynchops niger & o & & \\
\hline \multicolumn{4}{|l|}{ Columbidae } \\
\hline Columbina minuta & $0, \mathrm{~s}$ & $3,5,11$ & \\
\hline Patagioenas oenops $\ddagger$ & $\mathrm{s}$ & $1,18,19$ & VU, VU \\
\hline Zenaida meloda & $\mathrm{o}, \mathrm{s}$ & $3,7,9,11,12,17,20$ & \\
\hline Zenaida auriculata & $\mathrm{o}, \mathrm{s}$ & $1,3,5,7,9,12,15,17,18,20,21$ & \\
\hline Leptotila verreauxi & $0, \mathrm{~s}$ & $3,5,7,9,11,12,18,20,21$ & \\
\hline Geotrygon frenata & $\mathrm{s}$ & 1,5 & \\
\hline \multicolumn{4}{|l|}{ Cuculidae } \\
\hline Coccyzus melacoryphus & $9,12,18,19$ & & \\
\hline Coccyzus erythropthalmus & $\mathrm{s}$ & 5,18 & \\
\hline Coccyzus lansbergi & & 19 & \\
\hline Piaya cayana & $\mathrm{s}$ & $1,5,18$ & \\
\hline Crotophaga sulcirostris & $0, \mathrm{~s}$ & $3,7,9,11,12,14,20,21$ & \\
\hline Tapera naevia & $\mathrm{s}$ & 5,18 & \\
\hline Pseudoscops clamator & $\mathrm{s}$ & 18 & \\
\hline Asio flammeus & o & & \\
\hline \multicolumn{4}{|l|}{ Caprimulgidae } \\
\hline Chordeiles acutipennis & $\mathrm{o}, \mathrm{s}$ & $3,5,7,9,11,12,19,20$ & \\
\hline Systellura longirostris & $\mathrm{o}, \mathrm{s}$ & $1,2,3,4,5,10,15,19,21$ & \\
\hline Nyctidromus anthonyi & & 19 & \\
\hline Uropsalis segmentata & s & 1 & \\
\hline \multicolumn{4}{|l|}{ Apodidae } \\
\hline Streptoprocne rutila & $\mathrm{o}, \mathrm{s}$ & 3,21 & \\
\hline Streptoprocne zonaris & o & 21 & \\
\hline Chaetura pelágica & $\mathrm{s}$ & 1 & NT, LC \\
\hline \multicolumn{4}{|l|}{ Trochilidae } \\
\hline Doryfera ludovicae & s & 1 & \\
\hline Doryfera johannae & s & 5 & \\
\hline Colibri delphinae & $\mathrm{s}$ & 5 & \\
\hline Colibri thalassinus & $\mathrm{s}$ & 5 & \\
\hline Colibri coruscans & s & $1,2,3,4,18,19,21$ & \\
\hline Leucippus taczanowskii & $\mathrm{s}$ & $1,2,3,4,5,18,19$ & $\mathrm{e}$ \\
\hline Amazilia chionogaster & $\mathrm{s}$ & 5 & \\
\hline Amazilia amazilia & $0, \mathrm{~s}$ & $3,4,5,7,9,11,12,19,20,21$ & \\
\hline Amazilia franciae & $\mathrm{s}$ & $1,5,18$ & \\
\hline Adelomyia melanogenys & $\mathrm{o}, \mathrm{s}$ & $1,5,6,21$ & \\
\hline
\end{tabular}


Appendix (Continued)

\begin{tabular}{|c|c|c|c|}
\hline Taxon & EVD & SS & $\mathrm{CS}$ \\
\hline Heliodoxa rubinoides & s & 1 & \\
\hline Heliodoxa leadbeateri & s & 1,5 & \\
\hline Boissonneaua matthewsii & s & 1,5 & \\
\hline Aglaeactis cupripennis & $\mathrm{o}, \mathrm{s}$ & $1,4,5,10,21$ & \\
\hline Aglaeactis aliciae & $\mathrm{s}$ & $1,3,4,5,19$ & EN, VU, e \\
\hline Oreotrochilus estella & s & $1,4,5,10,18$ & \\
\hline Lafresnaya lafresnayi & $0, \mathrm{~s}$ & 1,21 & \\
\hline Coeligena coeligena & $\mathrm{S}$ & 1,5 & \\
\hline Coeligena torquata & s & 1,5 & \\
\hline Coeligena dichroura & $\mathrm{s}$ & 1,19 & $\mathrm{e}$ \\
\hline Coeligena iris & $0, \mathrm{~s}$ & $1,5,18,21$ & \\
\hline Ensifera ensifera & $\mathrm{s}$ & 1,19 & \\
\hline Pterophanes cyanopterus & s & $1,5,10$ & \\
\hline Patagona gigas & $\mathrm{o}, \mathrm{s}$ & $1,2,3,15,18,21$ & \\
\hline Heliangelus amethysticollis & $\mathrm{s}$ & 1 & \\
\hline Heliangelus viola & o & 21 & \\
\hline Eriocnemis luciani & s & 1 & \\
\hline Eriocnemis aline & $\mathrm{s}$ & 1,5 & \\
\hline Ocreatus underwoodii & $\mathrm{s}$ & 1,5 & \\
\hline Lesbia victoriae & $\mathrm{s}$ & $1,5,10$ & \\
\hline Lesbia nuna & $\mathrm{o}, \mathrm{s}$ & $1,3,5,18,21$ & \\
\hline Polyonymus caroli & $\mathrm{s}$ & $1,4,6,10,19$ & $\mathrm{e}$ \\
\hline Metallura tyrianthina & s & $1,4,5$ & \\
\hline Metallura theresiae & s & $1,5,19$ & $\mathrm{e}$ \\
\hline Metallura phoebe & $\mathrm{s}$ & $2,4,5,10,15,18$ & $\mathrm{e}$ \\
\hline Haplophaedia assimilis & $\mathrm{s}$ & 5 & \\
\hline Chalcostigma ruficeps & s & 1 & \\
\hline Chalcostigma stanleyi & $\mathrm{s}$ & $1,5,10$ & \\
\hline Opisthoprora euryptera & $\mathrm{s}$ & 1 & \\
\hline Aglaiocercus kingii & s & 1,5 & \\
\hline Schistes geoffroyi & $\mathrm{s}$ & 1 & \\
\hline Thaumastura cora & $\mathrm{s}$ & $3,4,5,19$ & \\
\hline Chaetocercus mulsant & $\mathrm{s}$ & $5,18,21$ & \\
\hline Chaetocercus bombus & $\mathrm{s}$ & 5,18 & VU, NT \\
\hline Myrtis fanny & $\mathrm{o}, \mathrm{s}$ & $1,5,7,9,12,18,19,20,21$ & \\
\hline Myrmia micrura & $0, \mathrm{~s}$ & 3 & \\
\hline \multicolumn{4}{|l|}{ Trogonidae } \\
\hline Pharomachrus auriceps & $\mathrm{s}$ & 4 & \\
\hline Trogon personatus & $\mathrm{s}$ & $1,4,5$ & \\
\hline \multicolumn{4}{|l|}{ Alcedinidae } \\
\hline Megaceryle torquata & 9 & & \\
\hline Chloroceryle americana & $0, \mathrm{~s}$ & $5,9,11$ & \\
\hline \multicolumn{4}{|l|}{ Bucconidae } \\
\hline Hapaloptila castanea & $\mathrm{s}$ & 1,4 & \\
\hline \multicolumn{4}{|l|}{ Capitonidae } \\
\hline Eubucco versicolor & s & 1 & NT, LC \\
\hline \multicolumn{4}{|l|}{ Ramphastidae } \\
\hline Aulacorhynchus prasinus & s & 1 & \\
\hline Aulacorhynchus huallagae & $\mathrm{s}$ & $1,5,19$ & EN, EN, e \\
\hline Andigena hypoglauca & s & $1,4,5,19$ & NT, NT \\
\hline \multicolumn{4}{|l|}{ Picidae } \\
\hline Picoides fumigatus & $0, \mathrm{~s}$ & $4,5,21$ & \\
\hline Veniliornis callonotus & & $7,9,12,20$ & \\
\hline Veniliornis nigriceps & $\mathrm{s}$ & 1 & \\
\hline Colaptes rubiginosus & & 7 & \\
\hline Colaptes rivolii & $\mathrm{s}$ & 1,4 & \\
\hline Colaptes atricollis & $\mathrm{o}, \mathrm{s}$ & $2,3,4,5,18,21$ & $\mathrm{e}$ \\
\hline Colaptes rupicola & $\mathrm{s}$ & $1,3,4,5,10$ & \\
\hline Campephilus pollens & $\mathrm{s}$ & 1,5 & \\
\hline
\end{tabular}


Appendix (Continued)

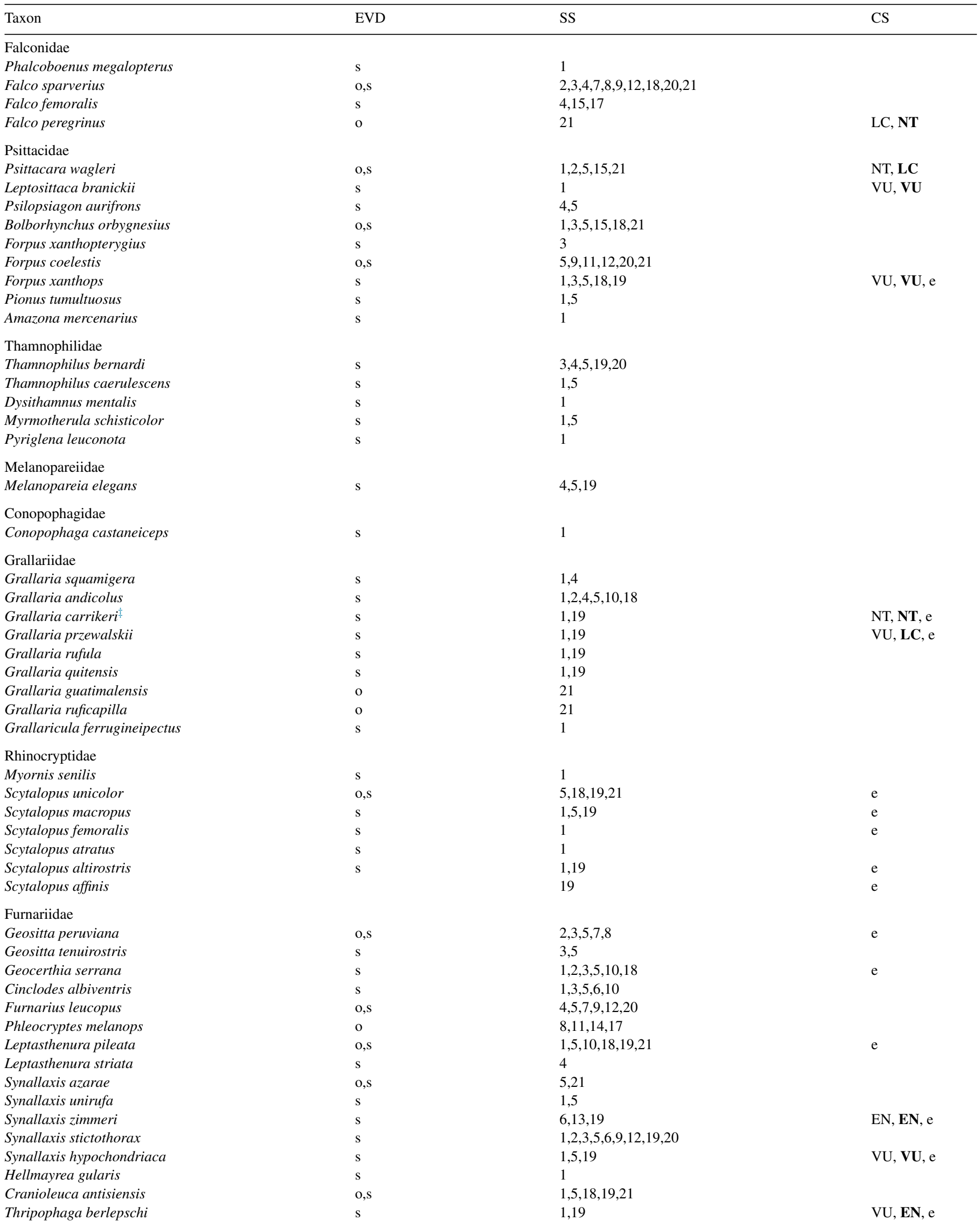


Appendix (Continued)

\begin{tabular}{|c|c|c|c|}
\hline Taxon & EVD & SS & $\mathrm{CS}$ \\
\hline Pseudasthenes cactorum & $\mathrm{o}, \mathrm{p}$ & & $\mathrm{e}$ \\
\hline Asthenes fuliginosa & $\mathrm{s}$ & 1,19 & \\
\hline Asthenes humilis & $\mathrm{s}$ & $1,2,5,10,18$ & \\
\hline Asthenes urubambensis & $\mathrm{s}$ & $1,5,19$ & NT, NT \\
\hline Asthenes flammulata & $\mathrm{s}$ & $1,2,5,10,19$ & \\
\hline Premnornis guttuliger & $\mathrm{s}$ & 1 & \\
\hline Premnoplex brunnescens & $\mathrm{s}$ & 1 & \\
\hline Margarornis squamiger & $\mathrm{s}$ & 1 & \\
\hline Pseudocolaptes boissonneautii & $\mathrm{s}$ & $1,4,5,19$ & \\
\hline Anabacerthia striaticollis & s & 1 & \\
\hline Syndactyla rufosuperciliata & s & 1 & \\
\hline Thripadectes holostictus & s & 1,19 & \\
\hline Thripadectes scrutator & $\mathrm{s}$ & 1 & \\
\hline Lochmias nematura & $\mathrm{s}$ & 1 & \\
\hline Xenops rutilans & $\mathrm{s}$ & 5 & \\
\hline Dendrocincla tyrannina & $\mathrm{s}$ & 1 & \\
\hline Xiphorhynchus triangularis & s & 1 & \\
\hline Lepidocolaptes lacrymiger & $\mathrm{s}$ & $1,4,5$ & \\
\hline Drymotoxeres pucherani & $\mathrm{s}$ & 1,7 & NT, NT \\
\hline \multicolumn{4}{|l|}{ Tyrannidae } \\
\hline Phyllomyias uropygialis & $\mathrm{o}, \mathrm{s}$ & 1,21 & \\
\hline Elaenia albiceps & $\mathrm{o}, \mathrm{s}$ & $1,5,18,21$ & \\
\hline Elaenia chiriquensis & $\mathrm{s}$ & 5 & \\
\hline Camptostoma obsoletum & $\mathrm{o}, \mathrm{s}$ & $1,3,5,7,9,12,19,20,21$ & \\
\hline Mecocerculus stictopterus & $\mathrm{o}, \mathrm{s}$ & $1,5,21$ & \\
\hline Mecocerculus leucophrys & $\mathrm{o}, \mathrm{s}$ & $1,5,21$ & \\
\hline Mecocerculus minor & $\mathrm{s}$ & 1 & \\
\hline Anairetes nigrocristatus & $0, \mathrm{~s}$ & $1,4,10,18,19,21$ & \\
\hline Anairetes reguloides & $0, \mathrm{~s}$ & $2,3,5$ & \\
\hline Anairetes flavirostris & $\mathrm{o}, \mathrm{s}$ & 5,21 & \\
\hline Anairetes parulus & $\mathrm{s}$ & 1,5 & \\
\hline Uromyias agraphia & $\mathrm{s}$ & $1,10,19$ & $\mathrm{e}$ \\
\hline Serpophaga cinerea & $\mathrm{o}, \mathrm{s}$ & 5 & \\
\hline Phaeomyias murina & $\mathrm{o}, \mathrm{s}$ & $1,2,3,4,5,19,21$ & \\
\hline Pseudocolopteryx acutipennis & $\mathrm{s}$ & 18 & \\
\hline Pseudotriccus pelzelni & s & 1 & \\
\hline Pseudotriccus ruficeps & $\mathrm{s}$ & 1 & \\
\hline Euscarthmus meloryphus & $0, \mathrm{~s}$ & $2,5,18,19,21$ & \\
\hline Phylloscartes ventralis & $\mathrm{s}$ & 5 & \\
\hline Mionectes striaticollis & $\mathrm{s}$ & 1,5 & \\
\hline Leptopogon taczanowskii & $\mathrm{s}$ & 1,5 & NT, LC, e \\
\hline Tachuris rubrigastra & $\mathrm{o}, \mathrm{s}$ & $4,8,11,17$ & \\
\hline Hemitriccus granadensis & $\mathrm{s}$ & 1 & \\
\hline Todirostrum cinereum & s & 18 & \\
\hline Rhynchocyclus fulvipectus & s & 1 & \\
\hline Tolmomyias sulphurescens & $\mathrm{s}$ & 1,5 & \\
\hline Platyrinchus mystaceus & $\mathrm{s}$ & 1,5 & \\
\hline Myiophobus flavicans & $\mathrm{s}$ & 1 & \\
\hline Myiophobus fasciatus & $\mathrm{s}$ & $1,2,3,5,18$ & \\
\hline Nephelomyias ochraceiventris & s & 1,19 & \\
\hline Pyrrhomyias cinnamomeus & $\mathrm{s}$ & 1 & \\
\hline Empidonax alnorum & $\mathrm{s}$ & 2 & \\
\hline Contopus fumigatus & $\mathrm{s}$ & 1,5 & \\
\hline Contopus cinereus & $\mathrm{o}, \mathrm{s}$ & $2,3,5,18,21$ & \\
\hline Sayornis nigricans & $\mathrm{s}$ & 18 & \\
\hline Pyrocephalus rubinus & $\mathrm{o}, \mathrm{s}$ & $3,4,7,9,11,12,14,19,18,20$ & \\
\hline Knipolegus poecilurus & $\mathrm{s}$ & 1,5 & \\
\hline Knipolegus aterrimus & $\mathrm{s}$ & $1,2,4,5,18$ & \\
\hline Muscisaxicola maculirostris & $\mathrm{s}$ & 1,5 & \\
\hline Muscisaxicola griseus & $\mathrm{s}$ & $1,5,15,18$ & \\
\hline Muscisaxicola flavinucha & $\mathrm{s}$ & 5 & \\
\hline Muscisaxicola rufivertex & $\mathrm{s}$ & $1,4,5$ & \\
\hline Muscisaxicola albilora & $\mathrm{s}$ & 1 & \\
\hline
\end{tabular}


Appendix (Continued)

\begin{tabular}{|c|c|c|c|}
\hline Taxon & EVD & SS & $\mathrm{CS}$ \\
\hline Agriornis montanus & s & $1,4,5$ & \\
\hline Agriornis albicauda & s & 3 & VU, VU \\
\hline Myiotheretes striaticollis & $0, \mathrm{~s}$ & $5,18,19,21$ & \\
\hline Polioxolmis rufipennis & $\mathrm{s}$ & $1,5,10,18$ & \\
\hline Tumbezia salvini & & 19 & NT, NT \\
\hline Ochthoeca frontalis & s & 1 & \\
\hline Ochthoeca cinnamomeiventris & $\mathrm{s}$ & 1,4 & \\
\hline Ochthoeca rufipectoralis & s & $1,5,10$ & \\
\hline Ochthoeca fumicolor & $\mathrm{s}$ & $1,5,10$ & \\
\hline Ochthoeca oenanthoides & $\mathrm{s}$ & $1,5,18$ & \\
\hline Ochthoeca piurae & $0, \mathrm{~s}$ & $5,13,19,21$ & $\mathrm{NT}, \mathbf{V U}, \mathrm{e}$ \\
\hline Ochthoeca leucophrys & $0, \mathrm{~s}$ & $1,4,5,10,18,19,21$ & \\
\hline Myiarchus semirufus $\ddagger$ & $\mathrm{s}$ & $1,3,5,19$ & EN, VU, e \\
\hline Myiarchus tuberculifer & $\mathrm{o}, \mathrm{s}$ & $1,3,5,21$ & \\
\hline Myiarchus cephalotes & $\mathrm{s}$ & 1,5 & \\
\hline Myiarchus tyrannulus & $\mathrm{s}$ & 1 & \\
\hline \multicolumn{4}{|l|}{ Cotingidae } \\
\hline Ampelion rubrocristatus & $0, \mathrm{~s}$ & $1,5,10,21$ & \\
\hline Doliornis sclateri $^{\ddagger}$ & $\mathrm{s}$ & 1,19 & VU, VU, e \\
\hline Phytotoma raimondii & $\mathrm{o}, \mathrm{s}$ & $1,3,4,19$ & EN, EN, e \\
\hline Pipreola riefferii & $\mathrm{s}$ & 1 & \\
\hline Pipreola intermedia & $\mathrm{s}$ & 1,4 & \\
\hline Pipreola arcuata & $\mathrm{s}$ & 1,4 & \\
\hline Pipreola pulchra & $\mathrm{s}$ & 1 & $\mathrm{e}$ \\
\hline \multicolumn{4}{|l|}{ Vireonidae } \\
\hline Cyclarhis gujanensis & $\mathrm{o}, \mathrm{s}$ & $1,5,18,21$ & \\
\hline Vireo olivaceus & $\mathrm{s}$ & 1,5 & \\
\hline \multicolumn{4}{|l|}{ Corvidae } \\
\hline Cyanolyca viridicyanus & s & 1,5 & NT, LC \\
\hline Cyanocorax yncas & s & 1,5 & \\
\hline \multicolumn{4}{|l|}{ Hirundinidae } \\
\hline Progne murphyi & o & & VU, LC \\
\hline Pygochelidon cyanoleuca & $0, \mathrm{~s}$ & $3,5,7,8,9,12,14,17,20,21$ & \\
\hline Orochelidon murina & $\mathrm{o}, \mathrm{s}$ & 1,21 & \\
\hline Orochelidon flavipes & $\mathrm{s}$ & 1 & \\
\hline Hirundo rustica & $0, \mathrm{~s}$ & 3,8 & \\
\hline Petrochelidon rufocollaris & o & & \\
\hline \multicolumn{4}{|l|}{ Troglodytidae } \\
\hline Troglodytes aedon & $\mathrm{o}, \mathrm{s}$ & $1,3,5,10,15,21$ & \\
\hline Troglodytes solstitialis & $\mathrm{s}$ & 1 & \\
\hline Cistothorus platensis & $\mathrm{s}$ & 1,5 & \\
\hline Campylorhynchus fasciatus & $0, \mathrm{~s}$ & $2,3,4,5,7,9,11,12,18,20,21$ & \\
\hline Cantorchilus superciliaris & $0, \mathrm{~s}$ & $1,3,9,12,20$ & \\
\hline Cinnycerthia peruana & $\mathrm{s}$ & 1 & $\mathrm{e}$ \\
\hline Henicorhina leucoptera & $\mathrm{s}$ & 1 & NT, NT \\
\hline Henicorhina leucophrys & s & 1,5 & \\
\hline Cyphorhinus thoracicus & $\mathrm{s}$ & 1 & \\
\hline
\end{tabular}


Appendix (Continued)

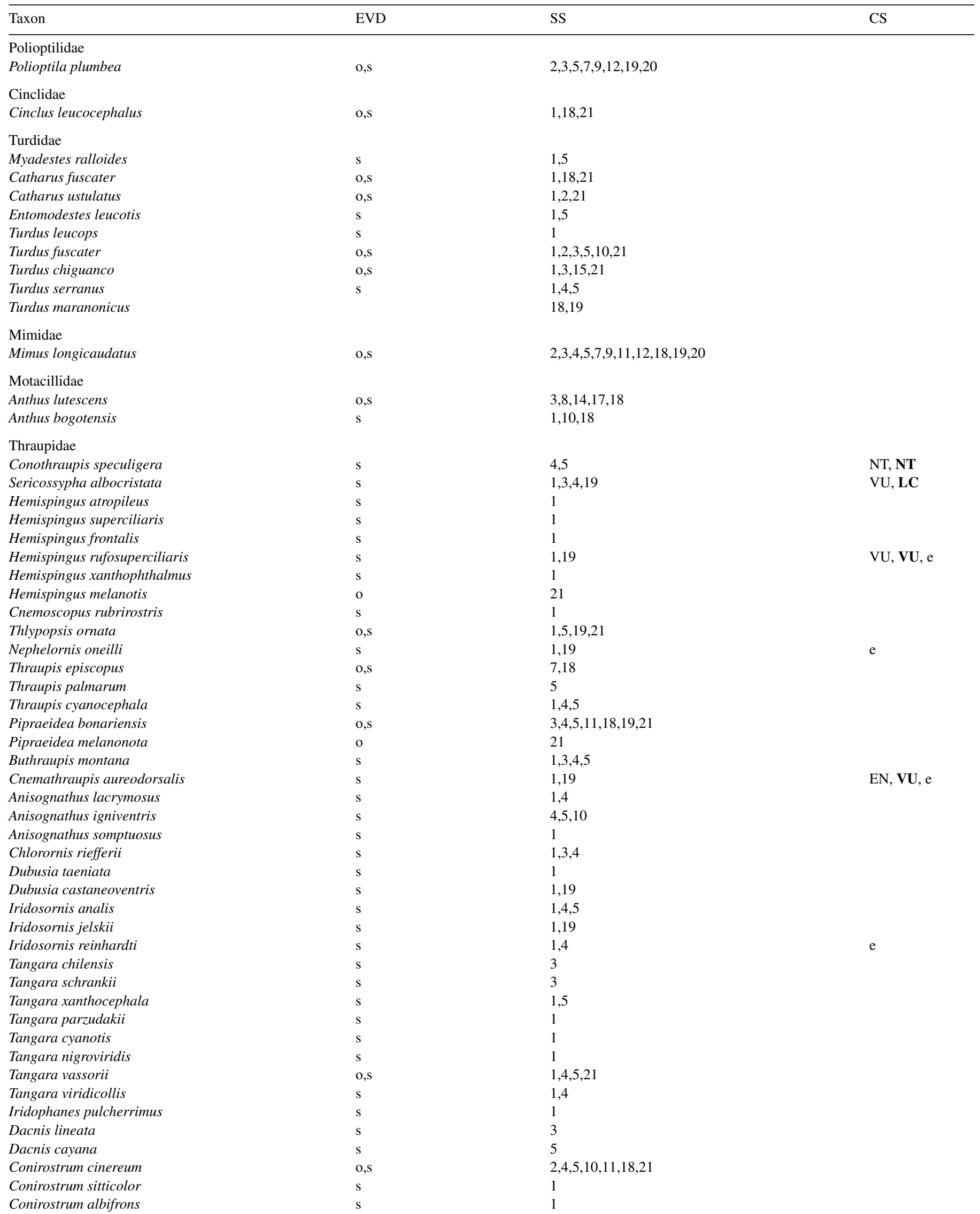


Appendix (Continued)

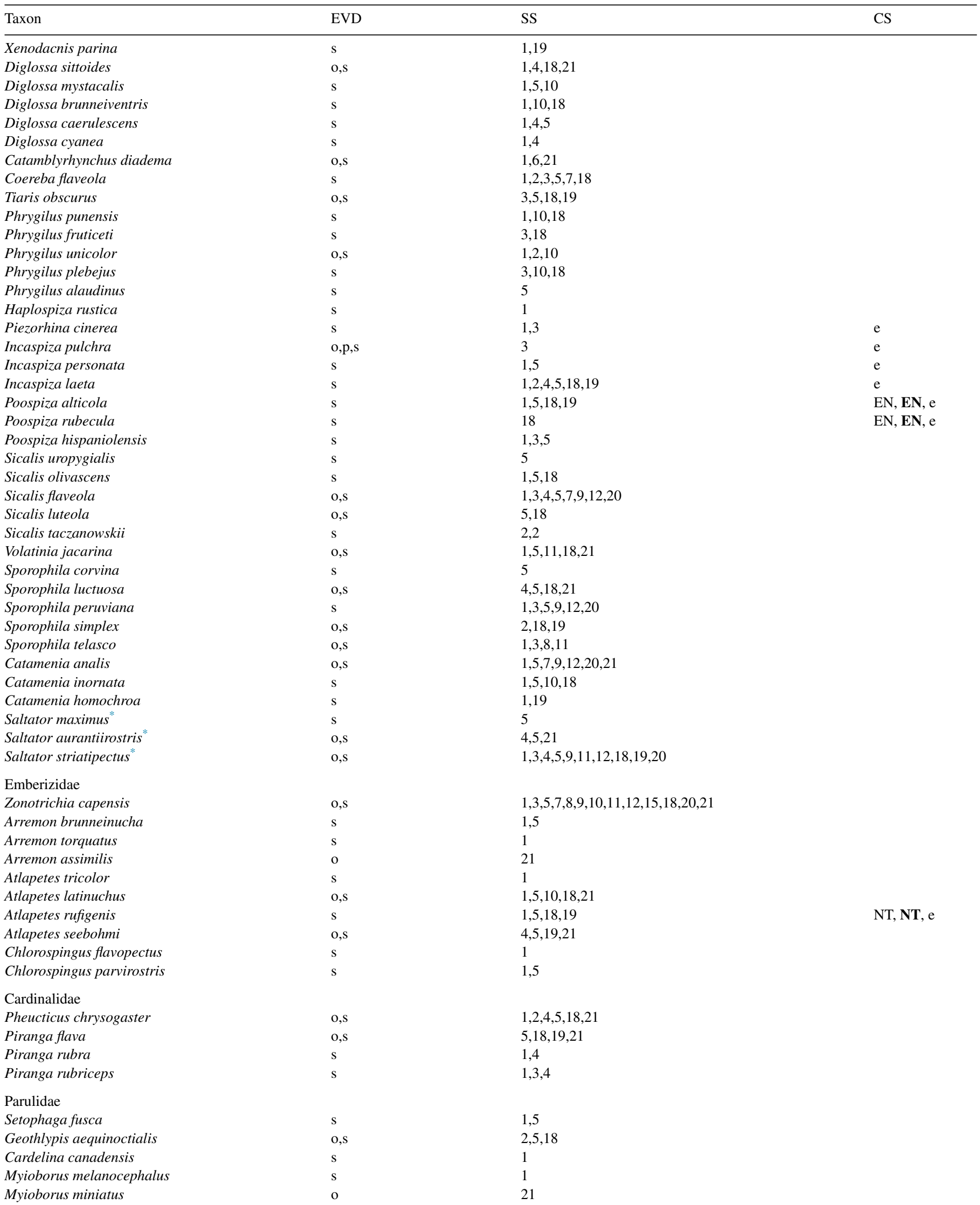




\section{Appendix (Continued)}

\begin{tabular}{lll}
\hline Taxon & EVD & SS \\
\hline Myiothlypis luteoviridis & $\mathrm{s}$ & 1,5 \\
Myiothlypis nigrocristata & $\mathrm{o}, \mathrm{s}$ & $1,5,18,21$ \\
Myiothlypis coronata & $\mathrm{s}$ & 1,5 \\
Basileuterus trifasciatus & $\mathrm{o}$ & 19,21 \\
Basileuterus tristriatus & $\mathrm{s}$ & 1,5 \\
Icteridae & & \\
Amblycercus holosericeus & $\mathrm{s}$ & 1 \\
Cacicus chrysonotus & $\mathrm{s}$ & 1 \\
Icterus graceannae & $\mathrm{s}$ & $3,4,5,19$ \\
Icterus mesomelas & $\mathrm{o}, \mathrm{s}$ & 5,18 \\
Dives warszewiczi & $\mathrm{o}, \mathrm{s}$ & $3,4,5,7,8,9,11,12,15,19,20,21$ \\
Molothrus bonariensis & $\mathrm{o}, \mathrm{s}$ & $3,4,5,7,9,11,12,20$ \\
Sturnella bellicosa & $\mathrm{o}, \mathrm{s}$ & $3,5,7,8,11,15,18$ \\
Fringillidae & & \\
Sporagra magellanica & $\mathrm{o}, \mathrm{s}$ & $1,2,3,5,9,11,12,18,20,21$ \\
Astragalinus psaltria & $\mathrm{s}$ & $3,5,18$ \\
Euphonia chlorotica & $\mathrm{s}$ & 1,19 \\
Euphonia cyanocephala & $\mathrm{s}$ & 5 \\
Chlorophonia pyrrhophrys & $\mathrm{s}$ & 1 \\
Passeridae & & \\
Passer domesticus & $\mathrm{o}$ & 8,11 \\
\hline
\end{tabular}

$¥$ Threatened species added in the last 10 years according to Ministerio de Agricultura $(2004,2014)$.

* Taxa considered as Incertae sedis.

\section{References}

Abanto, R., \& Carcelen, F. (2005). Reconocimiento preliminar de aves en el Área de Conservación Privada "Bosque Natural El Cañoncillo". In Libro de Resúmenes del VI Congreso Nacional de Ornitología. Chiclayo, Peru: VICNO.

Álvarez, B. (2001). Riqueza de especies y abundancia relativa de las aves marinas entre Salaverry y el Brujo (Thesis). La Libertad, Peru: Universidad Nacional de Trujillo.

Álvarez, C., \& Iannacone, J. (2008). Nuevos registros de aves en los humedales de Ventanilla, Callao, Perú. Biologist, 6, 68-71.

Angulo-Pratolongo, F. (2009). Perú. In C. Devenish, D. F. Díaz Fernández, R. P. Clay, I. Davidson, \& I. Yépez Zabala (Eds.), Important bird areas Americas - Priority sites for biodiversity conservation (BirdLife Conservation Series No. 16) (pp. 307-316). Quito, Ecuador: BirdLife International.

Angulo-Pratolongo, F., Palomino, W., Arnal, H., Aucca, C., \& Uchofen, O. (2008). Corredor de conservación de aves Marañón - Alto Mayo: Análisis de distribución de aves de alta prioridad de conservación e identificación de propuestas de áreas para su conservación. Cusco, Peru: Asociación Ecosistemas Andinos, American Bird Conservancy.

Ávalos, M. (1997). Inventario de las aves del Algarrobal del Moro (Thesis). La Libertad, Peru: Universidad Nacional de Trujillo.

Banco Central de Reserva del Perú. (2004). Región La Libertad: Cifras y reflexiones para el debate. Encuentro económico región La Libertad. Trujillo: BCRP Press.

Barrio, J. (2007). Elaboración de la lista de aves de los bosques de los alrededores del PV Chigualén. In PN Río Abiseo y determinación del símbolo para el circuito interpretativo. Informe interno CORBIDI-APECO-07-01. Lima: CORBIDI Press.

Becerra, J. (1981). Estudio ornitológico preliminar del monte Ribereño del río Moche 1981. Trabajo de habilitación para promoción docente. Programa Académico de Ciencias Biológicas. La Libertad, Peru: Universidad Nacional de Trujillo.

BirdLife International. (2015a). IUCN Red List for birds. http://www. birdlife.org 4.08.15)
BirdLife International. (2015b). Species factsheet: Eubucco steerii.. Downloaded from http://www.birdlife.org (accessed 02.09.15)

Bonaccorso, E., Guayasamin, J. M., Peterson, A. T., \& Navarro-Sigüenza, A. G. (2011). Molecular phylogeny and systematics of Neotropical toucanets in the genus Aulacorhynchus (Aves, Ramphastidae). Zoologica Scripta, 40, 336-349.

Brack, A. (1986). Ecología de un país complejo. In J. Mejía-Baca (Ed.), Gran geografía del Perú: naturaleza y hombre (pp. 175-319). Barcelona, Lima: Manfer-Mejía Baca.

Clements, J., \& Shany, N. (2001). A field guide to the birds of Peru. California: Ibis Publishing Company.

Cotterill, F. P. D. (1995). Systematics, biological knowledge and environmental conservation. Biodiversity and Conservation, 4, 183-205.

De la Cruz, C. (1996). Diversidad y densidad poblacional de las aves del algarrobal de Moro (Thesis). La Libertad, Peru: Universidad Nacional de Trujillo.

Del Hoyo, J., \& Collar, N. (2014). HBW and BirdLife international illustrated checklist of the birds of the World, volume 1. In J. del Hoyo, \& N. Collar (Eds.), Non-passerines (pp. 620-628). Barcelona: Lynx Edicions.

Derryberry, E., Claramunt, S., O'quin, K. E., Terry Chesser, A. A. R., Remsen, J. V., Jr., \& Brumfield, R. T. (2010). Pseudasthenes, a new genus of ovenbird (Aves: Passeriformes: Furnariidae). Zootaxa, 2416, 61-68.

Fjeldså, J. (1993). The avifauna of the Polylepis woodland of the Andean highlands: the efficiency of basing conservation priorities on patterns of endemism. Bird Conservation International, 3, 37-55.

Flanagan, J., Franke, I., \& Salinas, L. (2005). Aves y endemismo en los bosques relictos de la vertiente occidental andina del norte del Perú y sur del Ecuador. Bosques relictos del NO de Perú y SO de Ecuador en Weigend M., E. Rodríguez y C. Arana. The relict forest of northwest Peru and southwest Ecuador. Revista Peruana de Biología, 12, 185-194.

Franke, I. (1994). Ecology of the birds of the dry cloud forests of western Peru (Ph.D. Thesis). Aberdeen, UK: University of Aberdeen.

Franke, I. (2007). Historia de la ornitología peruana e importancia de las colecciones científicas de aves. Revista Peruana de Biología, 14, 159-164. 
Gastelo, D., Alva, W., del Busto, J., Kauffmann, F., \& Vásquez, C. (2004). Atlas regional del Perú: La Libertad. La Libertad, Peru: Ediciones Peisa S.A.

Gonzáles, O., \& Málaga, E. (1997). Distribución de aves en el Valle de Majes, Arequipa, Perú. Ornitología Neotropical, 8, 57-69.

Graham, G. L., Graves, G. R., Schulenberg, T. S., \& O’Neill, J. P. (1980). Seventeen bird species new to Peru from the Pampas de Heath. Auk, 97, 366-370.

Guarniz, S. (1997). Diversidad y densidad poblacional de las aves en la bocana del río Moche (Thesis). La Libertad, Peru: Universidad Nacional de Trujillo.

Herrera, E. (1980). Informe para el establecimiento de unidad de conservación en Calipuy. Lima: Instituto Nacional de Recursos Naturales, Ministerio de Agricultura.

Hughes, R. A. (1970). Note on the birds of the Mollendo district, southwest Peru. Ibis, 112, 229-241.

Koch, C. (2014). The herpetofauna of the Peruvian dry forest along the Andean Valley of the Marañón River and its tributaries, with a focus on endemic iguanians, geckos and tegus (Doctoral Thesis). Rheinischen Friedrich-Wilhelms University.

Lambert, F. R., \& Angulo-Pratolongo, F. (2007). Distribution, status and notes on the ecology of Purple-backed Sunbeam Aglaeactis aliciae in north Peru. Cotinga, 28, 21-26.

LoPresti, E., \& Angulo-Pratolongo, F. (2014). New bird distribution records for Lambayeque, Peru: Nomonyx dominicus (Linneaus, 1766) (Anatidae) and Incaspiza pulchra (Sclater, 1886) (Emberizidae). Check List, 10, 618-620.

Mark, T., Augustine, L., Barrio, J., Flanagan, J., \& Vellinga, W. P. (2008). New records of birds from the northern Cordillera Central of Peru in a historical perspective. Cotinga, 29, 108-125.

Martin-Alva, A., Florián Medina, A., \& Díaz Pillasca, H. (2013). Diversidad ornitológica del algarrobal El Cañoncillo. Infinitum, 3, 27-34.

Meléndez, V. (1976). Caprimulgidos de la provincia de Trujillo (Perú) (Thesis). La Libertad, Peru: Universidad Nacional de Trujillo.

Ministerio de Agricultura. (2004). Caracterización de especies amenazadas de fauna silvestre. D.S. $N^{\circ}$ 034-2004-AG. El Peruano, Lima: Editora Peru.

Ministerio de Agricultura. (2014). Decreto Supremo que aprueba la actualización de la lista de clasificación y categorización de las especies amenazadas de fauna silvestre legalmente protegidas. D.S. No 004-2014MINAGRI. El Peruano, Lima: Editora Peru.

Ministerio de Ambiente. (2011). Ecoregiones del Perú. Available from: http://geoservidor.minam.gob.pe/geoservidor/Archivos/Mapa/N53 ECORREGIONES.pdf (accessed 30.09.15)

Ministerio de Ambiente. (2015). Sistema Nacional de Áreas Naturales Protegidas por el Estado-SINANPE.. Available from: http://www.sernanp.gob.pe/ sernanp/archivos/biblioteca/mapas/ListaAnps_25082015.pdf (accessed 25.08.15)

Morrone, J. J., \& Escalante, T. (2012). Diccionario de biogeografía. México, D.F.: Facultad de Ciencias, UNAM.

Myers, N., Mittermeier, R. A., Mittermeier, C. G., da Fonseca, G. A. B., \& Kent, J. (2000). Biodiversity hotspots for conservation priorities. Nature, 403, 853-858.

Núñez-Zapata, J., \& Tiravanti, J. (2012). Extensión del rango de distribución norte de dos aves endémicas de Perú: Pseudasthenes cactorum e Incaspiza pulchra. Cotinga, 34, 87-90.

Olson, D. M., Dinerstein, E., Wikramanayake, E. D., Burgess, N. D., Powell, G. V. N., Underwood, E. C., et al. (2001). Terrestrial ecoregions of the world: a new map of life on Earth. Bioscience, 51, 933-938.

Parker, T. A., III. (1982). Observation of some unusual rainforest and marsh birds in southeastern Peru. Wilson Bulletin, 94, 477-493.

Parker, T. A., III, \& O’Neill, J. P. (1985). A new species and a new subspecies of Thryothorus wren from Peru. Ornithological Monographs, 36, 9-15.

Patterson, B. D., Stotz, D. F., Solari, S., Fitzpatrick, J. W., \& Pachecho, V. (1998). Contrasting patterns of elevational zonation for birds and mammals in the Andes of southeastern Peru. Journal of Biogeography, 25, 593-607.

Plascencia, A. (2001). Diversidad y densidad poblacional de las aves en los totorales de Huanchaco, Trujillo (Thesis). La Libertad, Peru: Universidad Nacional de Trujillo.
Pollack-Velásquez, L. E., Martin-Alva, A., Zelada, W., Huamán, E., Sarachaga, G., Torres, J., et al. (2003). Índices de diversidad de aves de la Ciudad Universitaria de la Universidad Nacional de Trujillo, julio - octubre, 2002. Rebiol, 23, 59-64.

Pollack-Velásquez, L. E., Zelada, W., Medina, C., \& Tiravanti, J. (2009). Phytotoma raymondi "Peruvian Plantcutter" registration in Viru, La Libertad department, Peru, 2009. Arnaldoa, 16, 125-128.

Puebla-Olivares, F., Bonaccorso, E., Espinosa-de los Monteros, A., Omland, K. E., Llorente-Bousquets, J. E., Peterson, A. T., et al. (2008). Speciation in the Emerald Toucanet (Aulacorhynchus prasinus) complex. Auk, 135, $39-50$.

Quiñonez, A., \& Tello, A. (2011). Nuevos registros de Coccyzus melacoryphus en la costa del Perú. Cotinga, 33, 130-132.

Remsen, J. V., Cadena, C. D., Jaramillo, A., Nores, M., Pacheco, J. F., Robbins, M. B., et al. (2015). A classification of the bird species of South America. American Ornithologists' Union. Available from: http://www.museum.lsu. edu/ Remsen/SACCBaseline07.htm (accessed 04.08.15)

Reynel, C., Pennington, R. T., \& Särkinen, T. (2013). ¿Cómo se formó la diversidad ecológica del Perú? Lima: Biblioteca Nacional del Peru.

Ridgely, R., \& Tudor, G. (1994). The birds of South America. Vol II: the Suboscines Passerines. Austin: University of Texas Press.

Rodríguez, E., \& Mora, M. (1994). El algarrobo de Moro (Prov. Chepen. Dpto. La Libertad). Estudio florístico, status y perspectivas. In Libro de resúmenes del XI Congreso Nacional de Biología. Tacna, Peru: UNJBG Press.

Rull, V. (2011). Neotropical biodiversity: timing and potential drivers. Trends in Ecology and Evolution, 26, 508-513.

Salvin, O. (1895). On the birds collected in Peru by Mr. O. T. Baron. Novitates Zoologicae, 2, 1-22.

Särkinen, T. E., Marcelo-Peña, J. L., Yomona, A. D., Simon, M. F., Pennington, R. T., \& Hughes, C. E. (2011). Underestimated endemic species diversity in the dry inter-Andean Valley of the Río Marañón, northern Peru: an example from Mimosa (Leguminosae, Mimosoideae). Taxon, 60, 139-150.

Schmitt, C. J., Schmitt, D. C., Tiravanti, J. C., Angulo-Pratolongo, F. P., Franke, I., Vallejos, L. M., et al. (2013). Avifauna of a relict Podocarpus forest in the Cachil Valley, north-west Peru. Cotinga, 35, 15-23.

Schulenberg, T., Stotz, D., Lane, D., O’Neill, J., \& Parker, T., III. (2007). Birds of Peru. Princeton, NJ: Princeton University Press.

Senner, N. R., \& Angulo-Pratolongo, F. (2014). Atlas de las aves playeras del Perú. Sitios importantes para su conservación. Lima, Perú: Ministerio del Ambiente Press. CORBIDI.

Sullivan, B. L., Wood, C. L., Iliff, M. J., Bonney, R. E., Fink, D., \& Kelling, S. (2009). eBird: a citizen-based bird observation network in the biological sciences. Biological Conservation, 142, 2282-2292.

Stattersfield, A., Crosby, M., Long, A., \& Wege, D. (1998). Endemic bird areas of the world: priorities for biodiversity conservation. Bird Life Conservation Series $N^{\circ}$ 7. Cambridge, UK: Bird Life International.

Terborgh, J. W., Fitzpatrick, J. W., \& Emmons, L. (1984). Annotated checklist of birds and mammal species of Cocha Cashu Biological Station, Manu National Park, Peru. Fieldiana Zoology, 21, 1-29.

Vallejos-Vardales, L., Saldaña-Ugaz, I., Pollack-Velásquez, L., \& Tiravanti, J. (2013). Registros del Aguilucho de Ala Ancha (Buteo platypterus) en zonas urbanas de Trujillo, La Libertad (2010-2013). Boletín Informativo UNOP, $8,59-65$.

Valqui, T. (2004). Where to watch birds in Peru. Lima: Thomas Valqui.

Venegas, P. J., Townsend, J. H., Koch, C., \& Böhme, W. (2008). Two new sympatric species of leaf-toed geckos (Gekkonidae: Phyllodactylus) from the Balsas Region of the Upper Marañon Valley, Peru. Journal of Herpetology, 42, 386-396.

Walker, B., Stotz, D. F., Pequeño, T., \& Fitzpatrick, J. W. (2006). Birds of the Manu Biosphere Reserve. Fieldiana Zoology, 110, 23-49.

Witt, C. C., \& Lane, D. F. (2009). Range extensions for two rare high-Andean birds in central Peru. Cotinga, 31, 90-94.

Zamora, C. (1996). Mapa de las ecorregiones. In L. Rodríguez (Ed.), Diversidad biológica del Perú (pp. 137-142). Lima: FANPE GTZ-INRENA. 